Back numbers of the Proceedings are in limited supply. Vols 62 (1996) to 76 (2010), excluding vol. 64 which is out of print, are available at $£ 35$ each. Please check with the printers for the availability of earlier copies, which are priced at $£ 25$ each. The current volume is $£ 45$ to non-members, $£ 30$ to members. A sum equivalent to $20 \%$ of the total order value should be added to overseas orders to assist with postage. Orders may be sent to Derry Print Limited, Glaisdale Parkway, Bilborough, Nottingham NG8 4JQ, England, accompanied by full payment, with cheques made payable to the Prehistoric Society. 


\section{CONTENTS VOL. 77, 2011}

1. A New Context for Rock Art: a Late Neolithic and Early Bronze Age Ritual Monument at Fylingdales, North Yorkshire. By BLAISE VYNER

2. Diversity Rules. On Late Prehistoric Settlement of the Eastern Netherlands and the Need for Regionally Specific Models. By ROY VAN BEEK

3. An Exotic Early Bronze Age Funerary Assemblage from Stanbury, West Yorkshire. By JANE RICHARDSON and BLAISE VYNER

4. Close to the Edge: New Perspectives on the Architecture, Function and Regional Geographies of the Coastal Promontory Forts of the Castlemartin Peninsula, South Pembrokeshire, Wales. By LOUISE BARKER and TOBY DRIVER

5. On the Beach: New Discoveries at Harlyn Bay, Cornwall. By ANDY M. JONES, JANE MARLEY, HENRIETTA QUINNELL and STEVE HARTGROVES

6. A Re-appraisal of the Evidence for Violence in the Late Iron Age Human Remains from Maiden Castle Hillfort, Dorset, England. By REBECCA C. REDFERN

Page 111

7. Excavations at a Neolithic Enclosure on The Peak, near Birdlip, Gloucestershire. By TIMOTHY DARVILL

Page 139

8. 'Fancy Objects' in the British Iron Age: Why Decorate? By JODY JOY

Page 205

9. Beccles Triple Post Alignment, Beccles Marshes, Suffolk: Excavation and Palaeoenvironmental Analyses of an Iron Age Wetland Site. By BENJAMIN R. GEAREY, HENRY P. CHAPMAN, ANDREW J. HOWARD, KRISTINA KRAWIEC, MICHAEL BAMFORTH, WILLIAM G. FLETCHER, THOMAS C.B. HILL, PETER MARSHALL, EMMA TETLOW and IAN TYERS

Page 231

10. Death, Decapitation and Display? The Bronze and Iron Age Human Remains from the Sculptor's Cave, Covesea, North-east Scotland. By IAN ARMIT, RICK SCHULTING, CHRISTOPHER J. KNÜSEL and IAN A.G. SHEPHERD $†$

Page 251

11. Towards Synthesis: Research and Discovery in Neolithic North-East England. By CLIVE WADDINGTON

Page 279

12. The Excavation of Duddo Stone Circle, Northumberland. By BENJAMIN EDWARDS, ROGER MIKET and ROSIE BISHOP

\section{Shorter contributions}

13. Hillforts, Emotional Metaphors, and the Good Life: a Response to Armit. By GARY LOCK 